\title{
CORPORATE GOVERNANCE, CREDIT RISK, AND FINANCIAL LITERACY FOR SMALL MEDIUM ENTERPRISE IN INDONESIA
}

\author{
Mutamimah MUTAMIMAH ${ }^{\circledR 1}{ }^{*}$, Mochammad THOLIB $^{1}$, Robiyanto ROBIYANTO ${ }^{2} 2$ \\ ${ }^{1}$ Faculty of Economics, Universitas Islam Sultan Agung (UNISSULA), 50112 Semarang, Central Java, Indonesia \\ ${ }^{2}$ Faculty of Economics and Business, Satya Wacana Christian University, 50711 Salatiga, Indonesia
}

Received 29 June 2020; accepted 29 April 2021

\begin{abstract}
The problem of SMEs in Indonesia as a "high-risk borrower" that has not been resolved until today. The purposes of this study was to analyze the financial literacy as mediating between corporate governance and SMEs' credit risk in Indonesia. This sample method used purposive sampling: 1273 units of Trade and Service SMEs fostered by Central Java that received credit in 2018. Twenty percent of the totals were taken, so the total was 255 samples. The data collection technique used questionnaires and interviews. The number of questionnaires distributed were 255 with a response rate of $95 \%$, so resulting 242 respondents. Data analysis used descriptive and Regression Method. The corporate governance shown by responsibility, independence, and fairness did not affect SMEs' credit risk. In other words, transparency and accountability is effective in reducing SMEs' credit risk. Also, financial literacy can strengthen the influence of transparency, accountability, and responsibility in reducing credit risk for SMEs in Indonesia.
\end{abstract}

Keywords: corporate governance, financial literacy, credit risk, Small Medium Enterprises.

JEL Classification: G34, G53.

\section{Introduction}

In developing country Small Medium Enterprises (SMEs) have important role at economic growth, but it has limited financing (Mutezo, 2013), do not have collateral and do not have adequate financial reports (Maseko \& Manyani, 2011). SMEs have high-risk borrower (Ciftci et al., 2019; Mutamimah \& Hendar, 2017). Credit risk occurs when SMEs as debtors fail to pay off debt on time (Kolapo et al., 2012). The strategy to reduce credit risk is implement of corporate governance (Saeed et al., 2018). The existence of Corporate Governance (CG) can eliminate asymmetric information and credit risk can be reduced. Asymmetric information is occurred when the information held by banks is smaller than SMEs, which encourages the moral hazard in the use of capital by SMEs, thereby increasing credit risk. However, corporate governance as the form of mechanisms and structures to regulate, monitor and control the behavior of SME managers will be able to reduce the moral hazard in the use of capital, increase transparency, accountability, fairness, and responsibility which can eliminate asymmetric information between banks and SMEs, so that can reduce credit risk. The emergence of conflict is explained by agency theory (Jensen \& Meckling,
1976). Banking as the principal gives confidence to SMEs as agent to be able to manage the capital properly. However, asymmetric information encourages SME managers to carry out opportunistic behavior to prioritize their interests which will harm creditors and other stakeholders. The CG in SMEs is different from CG in large companies, because SMEs in Indonesia was still a one-man show and family business, majority of SMEs in Indonesia have not yet gone public, so agency problems in SMEs in this study is a problem between creditors and debtors.

Researches on the influence of CG on credit risk show inconsistent results and inconclusive. Postnova (2012) stated that CG cannot reduce credit risk. However, Dao and Pham (2015) showed that CG can decrease of credit risk. This research is motivated by the unresolved problem of SMEs credit risk and a research gap. The results of previous studies do not include financial literacy as a moderating variable. Hussain et al. (2018) said that financial literacy can decrease of asymmetric information.

Based on result of previous researchers to make novelty by including financial literacy as a moderating variable. Financial literacy as a form of intangible assets must be owned by SME managers as explained by Resource Based View Theory (Wernerfelt, 1984). Previous researches

*Corresponding author. E-mail: mutamimah@unissula.ac.id

Copyright $\odot 2021$ The Author(s). Published by Vilnius Gediminas Technical University

This is an Open Access article distributed under the terms of the Creative Commons Attribution License (http://creativecommons.org/licenses/by/4.0/), which permits unrestricted use, distribution, and reproduction in any medium, provided the original author and source are credited. 
ignore of financial literacy. Fatoki (2014) said that good financial literacy, SMEs manager should make the right financial decisions, so that they can pay their loans on time. Moreover, Okello et al. (2017) said that financial literacy make it easier to choose the strategic of funding sources. Hence, the existence of financial literacy can minimize credit risk.

The research is to analyse of financial literacy in moderating the effect of CG on SMEs' credit risk in Indonesia. Contribution of this result to the development of corporate governance model based on financial literacy as explained by the Agency Theory and Resource-Based View Theory so that credit risk can be reduced. Also, this research is beneficial for banks as a basis for lending to SMEs and also beneficial for the government as a basis for improving regulations related to corporate governance based on financial literacy.

\section{Review of literature}

\subsection{Small Medium Enterprises in Indonesia}

SMEs have a strategic role in employment and economic growth, because the majority of business units in Indonesia are SMEs with $99.9 \%$ of all business units, and $0.01 \%$ is a large business. SMEs in Indonesia have some characteristics: the family business; management functions held by one person, do not go public on the Stock Exchange (Kurniawati et al., 2018), limited financial access (Maseko \& Manyani, 2011) and credit risk for non SMEs are lower than SMEs (Mutamimah \& Hendar, 2017). This shows that SMEs have a vast opportunity to be studied in order to contribute to economic empowerment and reduce poverty.

\subsection{Corporate Governance (CG) and credit risk}

CG is based on agency theory, because as agents, SMEs will prioritize their interests than the others. SMEs' CG becomes a framework, processes, and attitudes to enhance value, reputation, and business sustainability. CG can increase the confidence of creditors towards SMEs (Abor \& Adjasi, 2007). The quality of mechanisms is determined by internal mechanisms for corporate governance implementation (Handriani \& Robiyanto, 2019; Mutamimah, 2020). CG in SMEs can reduce risk of debt effectively.

Transparency as a CG whereby SME managers must report the financial performance precisely, quickly, and correctly to banks and other stakeholders (Fülöp, 2014). Ansong (2013) state that the improper SMEs transparency results in credit risk. Therefore, SMEs' transparency is needed for creditor, and SMEs' financial management must be better. The existence of transparency will eliminate asymmetric information so that credit risk can be reduced. $H_{1}$ : Transparency has a negative effect on credit risk.

SMEs must comply the rules, monitoring and evaluation system both internally and externally as a form of SMEs' accountability. When SMEs' managers conduct periodic monitoring and evaluation of all SME activities, it can immediately be found if there are irregularities in the management and SMEs can work according to procedures and plans, so that SMEs pay off debts on time. If SMEs can implement corporate governance effectively, SMEs can manage risk well (Ansong, 2013).

$\mathrm{H}_{2}$ : accountability has a negative effect on credit risk.

SMEs should compile financial reports periodically, obeying the laws and regulations as a form of responsibility. Hanifah (2015) found that the implementation of SMEs' responsibility is very good. In other words, SMEs have complied with laws and regulations, and have been responsible to banks and stakeholders, so that it can reduced credit risk.

$\mathrm{H}_{3}$ : Responsibility affects credit risk.

This principle of independence that SMEs must be professional and objective so they can produce objective decisions. Hanifah (2015) stated that independence on SMEs on average is $61 \%$, SMEs manager can professionally manage without conflict of interest, so it will reduce credit risk.

$\mathrm{H}_{4}$ : Independence affects credit risk.

Fairness in SMEs has a direct impact on recording and accounting standards and information disclosure that can increase creditors' trust (Abor \& Adjasi, 2007). Hanifah (2015) showed that SMEs have implemented fairness in their business operations. This means, SMEs have implemented a system of justice and equality in fulfilling the rights of banks and other stakeholders, so that it will reduce credit risk.

$H_{5}$ : Fairness has a negative effect on credit risk.

\subsection{Financial literacy, corporate governance and credit risk}

The Resource-Based Theory explained that corporate performance and sustainability are determined by the internal resources (Wernerfelt, 1984). Financial literacy as internal resource becomes an intangible assets: knowledge, skills, experience, and reputation (Eniola \& Entebang, 2015). According to Lusardi and Mitchell (2014), financial literacy is financial management knowledge to achieve prosperity. Fatoki (2014) stated that by having good financial skills, businesses should make financial decisions appropriately so that they can pay their loans on time. Smith (2011) stated that if SME managers do not have financial literacy, hence causing losses in their business. Financial literacy can moderate information gaps and improve professional financial management it can also reduce credit risk (Adomako et al., 2016). Lusardi and Scheresberg (2013) said that there is financial literacy can minimize of the loan cost. Someone who has knowledge, understanding and skills of financial management in calculating, analyzing, selecting, comparing, and choosing various types of credit will receive high quality credit so improve the cost of debt. Likewise, if someone does not have the knowledge and skills of financial management in calculating, analyzing, selecting, comparing and choosing various types of credit offered by various financial institutions, then they 
will get low quality credit, so that the cost of debt is huge. This is explained by Fatoki (2014) that if the financial literacy possessed by business people, they can make accurate and efficient financial decisions.

If SMEs are knowing, understanding, and having skills in financial management, they can strengthen in delivering information in a timely, correct, and accurate manner to banks and other stakeholders. Fatoki (2014) stated that to get better financial decision, SMEs' managers have good financial literacy. Wise (2013) added that literacy of financial allows managers to record financial statements that can facilitate managerial decision making. The ability to monitor financial statements conducted by SMEs can reduce credit risk.

$H_{6}$ : Financial Literacy can strengthen the effect of transparency on credit risk.

Knowledge, understanding, skills of financial management, and credit management can strengthen SME managers in implementing a clear system of business accountability so that SMEs can pay off debts on time. Financial literacy is divided into two, namely external and internal literacy of financial (Wise, 2013). It can support SME managers in accountability to reduce credit risk.

$H_{7}$ : Financial literacy can strengthen the effect of accountability on credit risk.

Adomako et al. (2016) stated that SMEs' managers must have knowledge, understanding, and skills in choosing various alternatives financial decision choices as a form of SMEs' responsibility. Knowledge, understanding, and skills of SMEs' financial management can strengthen SMEs in financial reports, obey the laws and regulations as a form of accountability to financial institution and others, so that it can reduce credit risk.

$H_{8}$ : Financial literacy can strengthen the effect of responsibility on credit risk.

Financial literacy is a competency that must be retained by SME managers. Mutegi et al. (2015) said that SME's manager who have good financial literacy can pay the loan in the scheduled time and increases the creditworthiness of SMEs. Okello et al. (2017) stated financial knowledge can aid manager to minimize credit risk in the corporation. The higher the knowledge, understanding, and skills of SMEs in managing finances, the better it strengthens SMEs to be professional without conflicting interests or pressure from any party. Thus, SMEs can make decisions objectively and no party is harmed so that credit risk can be reduced.

$H_{9}$ : Financial literacy can strengthen the effect of independence on credit risk.

Glaser and Walther (2013) stated that financial literacy can help managers in making financial decision and managing credit risk. Knowledge, understanding, skills of SMEs in managing finances and possible impacts that occur can strengthen SMEs to be fair and equal in fulfilling the rights of internal and external parties based on agreements, laws, and regulations. Hussain et al. (2018) stated that financial literacy can reduce asymmetry information, collateral deficits, and prevent SMEs from doing adverse business management.
$H_{10}$ : Financial Literacy can strengthen the effect of fairness on credit risk.

\section{Methodology}

This is an explanatory research which aims to test theories or hypotheses. This study used purposive sampling so that the sample selection was right and on target according to the research topic, with criteria as follows: a) Trade and Service of SMEs that had access of financing from banks in Central Java, with the total of 1273 SMEs, this sector is able to provide the highest contribution to Gross Domestic Product $(23.72 \%)$. With the characteristics of this homogeneous SMEs, number of samples were $20 \%$ from population, so that total of SMEs was $255(20 \% \times 1273$ SMEs).

The number of questionnaires distributed was 255, however the fully completed questionnaires (the response rate $95 \%$ ) so that 242 questioners were analyzed. The primary data through interviews and questionnaires. This method was carried out because SMEs did not have documented data, such as corporate governance, credit risk and financial literacy. The questionnaire with a Likert scale used 5 points measurement. The dependent variable is credit risk, while the dependent variable are corporate governances: transparency, accountability, responsibility, independence, and fairness (Hanifah, 2015; Kurniawati et al., 2018), and moderating variable is financial literacy. To make it easier to collect data through questionnaires and interviews, all variable used indicator. Transparency of SMEs: convey corporate information to creditors and to stakeholders in an open, fast and accurate manner, publish financial reports for tax purposes. Accountability: SMEs have business guidelines clearly and detailed business monitoring and evaluations. Responsibility: SMEs always provide financial reports to authorities, provide social program to the community and stakeholders, obey laws and regulations. Independent: SMEs always act professionally in decision making, SMEs are impartial in decision and action, and never prioritize their personal and group interests. Fairness: SMEs are always balanced in treating all stakeholders and providing relevant information for the owner.

This study used descriptive and Moderating Regression Analysis, test of every questioner indicator, and test of assumption classic. This equation as follows:

$$
\begin{aligned}
& \mathrm{CR}=a+\beta_{1} \mathrm{TR}+\beta_{2} \mathrm{ACC}+\beta_{3} \mathrm{RSP}+\beta_{4} \mathrm{IND}+ \\
& \beta_{5} \mathrm{FRN}+\beta_{6} \mathrm{FL}+\beta_{7} \mathrm{TRFL}+\beta_{8} \mathrm{ACCFL}+\beta_{9} \mathrm{RSPFL}+ \\
& \beta_{10} \mathrm{INDFL}+\beta_{11} \mathrm{FRN} \mathrm{FL}+e .
\end{aligned}
$$

Notes: CR - credit risk, $a$ - constant, $\beta_{1}, \beta_{2}, \beta_{3}, \cdots$ $\beta_{n}$ - regression coefficient, TR - Transparency, ACC - accountability, RSP - responsibility, IND - independence, FRN - fairness, FL - financial literacy (moderating variable), $e$ - error. 


\section{Results and discussion}

Result and discussion: respondent profile, variable description, instrument and classical assumption test result, and multiple regression analysis result.

Respondent profile. In total, there are 242 SMEs managers in Indonesia, with the profiles are as follows: The majority of respondents are men (51\%) and women (49\%). Most of them are aged between $28-38$ years (37\%) and $39-49$ years (22\%). This means that the majority of SME managers in Indonesia are in the productive age which is very easy to develop financial literacy. Education of SME managers is dominated by high schools (38\%), and (12\%) have elementary school. SMEs in Indonesia become a strategic method for expanding employment opportunities. The majority of SMEs were detailed as their own (53\%), family owned (29\%), and partnerships (10\%). The majority of SMEs (50\%) do not have financial report, and (34\%) simple records and only (12\%) of them record financial statements.

The variable description is obtained from the responses of respondents in the form of a Likert scale, which is a scale of 5 . Before doing the variable description, it is preceded by determining the range of the respondent's answer scale with the following formula:

$$
\mathrm{SR}=\frac{(m-n)}{C} \text {. }
$$

Note: $\mathrm{SR}=$ Scale of Range; $m=$ Highest measurement; $n=$ Lowest measurement; $C=$ Sum of classes.

Thus

$$
\mathrm{SR}=\frac{(5-1)}{3}=1.33 \text {. }
$$

Variable description. Based on respondents' answers, it is categorized that: low reflects $(1-2.33)$, moderate reflects (2.34-3.67) and high reflects (3.68-5). The average value of the transparency is 3.4107 (moderate) that SMEs have delivered financial information to banks and other stakeholders correctly, quickly and precisely, but not maximally. The accountability an average value of 3.3285 (moderate), means that SMEs have not been maximized in carrying out their business activities in the form of clarity of functions. The responsibility with average value of 3.4603 (moderate), that SMEs have not optimized their responsibilities and compliance with law and regulation. Independence is 3.5140 (moderate), that most SMEs have not applied the principles of management yet and there are influenced from other parties, so that decision-making has not objective. Fairness with a value of 3.404 (moderate), means that SMEs have treated all stakeholders fairly, relevant laws, and regulations, but not maximal yet. Financial literacy with a value of 3.438 (moderate) means that SMEs' managers have the knowledge, understanding, and skills of financial management and risk management, but not yet reach maximal. The credit risk with value of 3.7680 (high) means that unpayment high, so it is very difficult to manage borrowed funds and encourage high credit risk (Andrews \& Gikunoo, 2011; Maseko \& Manyani, 2011; Mutezo, 2013).

The instrument test results showed that all variables used in this study (transparency, accountability, responsibility, fairness, independence, financial literacy, and credit risk) are valid. The reliability test results with a Cronbach Alpha is $0.861>0.60$, all indicators in the variables of transparency, accountability, responsibility, fairness, independence, financial literacy, and credit risk are reliable or consistent from time to time. The classical assumption test results showed that the Kolmogorov-Smirnov's sig. (5\%) of $0.351>0.05$, meaning that data is normally distributed. Multicollinearity test results indicate that all variables: transparency, accountability, responsibility, fairness, independence, and financial literacy have a VIF value of less than 10, meaning that multicollinearity does not occur. Heteroscedasticity test is done by using the Glejser test, the results indicate that the transparency, accountability, responsibility, fairness, independence, and financial literacy have values $>0.05$, meaning that there is no heteroscedasticity.

Table 1. Regression result

\begin{tabular}{|l|c|c|c|c|}
\hline & Coefficient & SE & $\mathrm{t}$ & Sign \\
\hline $\mathrm{a}$ & 6.751 & 1.151 & 5.862 & .000 \\
\hline TR & -.627 & .227 & -2.759 & .007 \\
\hline ACC & -.623 & .242 & -2.574 & .011 \\
\hline RSP & -.531 & .284 & -1.871 & .063 \\
\hline IND & .192 & .271 & .706 & .481 \\
\hline FRN & .426 & .262 & 1.626 & .105 \\
\hline FL & -1.059 & .315 & -3.367 & .001 \\
\hline TR $\times$ FL & .165 & .057 & 2.910 & .004 \\
\hline ACC $\times$ FL & .148 & .065 & 2.273 & .024 \\
\hline RSP $\times$ FL & .170 & .073 & 2.347 & .020 \\
\hline IND $\times$ FL & -.023 & .075 & -.308 & .759 \\
\hline FRN $\times$ FL & -.083 & .069 & -1.199 & .232 \\
\hline
\end{tabular}

Notes: SE - Standard Error; a - constant; CR - credit risk; $\beta_{1}, \beta_{2}$, $\beta_{3}, \ldots \beta$ - regression coefficient; TR - transparency; ACC - accountability; RSP - responsibility; IND - independence; FRN fairness; FL - financial literacy; e - error.

Hypothesis 1 states that transparency can decrease the credit risk. Table 1 show that transparency has a coefficient -0.627 , $t$-value of -2.759 which significant at 0.007 , because the significance level is less than 0.05 , so hypothesis 1 is accepted. The results show that transparency as a corporate governance mechanism influence credit risk at $5 \%$ level of significance. This indicates that SMEs publish the financial information to creditors and stakeholders accurately, so it can reduce credit risk. These results doesn't support Andrews and Gikunoo (2011); Maseko and Manyani (2011); Mutezo (2013), and also doesn't support Dzigba (2015); Postnova (2012) that corporate governance cannot reduce credit risk. However, this results 
support Dao and Pham (2015); Ko et al. (2019) that found corporate governance can reduce credit risk.

Hypothesis 2 states that accountability able to reduce on credit risk. Table 1 show that accountability has a coefficient -0.623 , $t$-value of -2.574 which significant at 0.011 , because the significance $<0.05$, so accepted the hypothesis 2. The accountability can decrease risk of loan at the $5 \%$ level of significance. This finding support Dao and Pham (2015); Ko et al. (2019) that corporate governance can reduce credit risk. However, this results doesn't support research by Dzigba (2015); Kryvko and Reichling (2012); Postnova (2012), that corporate governance cannot reduce credit risk.

Hypothesis 3 states that responsibility has a negative effect on credit risk. Table 1 show that responsibility has a coefficient $-0.531, \mathrm{t}$-value of -1.871 which significant at 0.063 , because the significance level is greater than 0.05 so hypothesis 3 is rejected. Responsibility as a corporate governance mechanism cannot reduce credit risk. The level of responsibility for SMEs in Indonesia is poor (Hanifah, 2015), SMEs do not provide documented of social assistance to communities because there are no binding regulations requiring SMEs to do so. Likewise, SMEs have not fully complied with laws and regulations and are accountable to creditors and other stakeholders, because the characteristics of SMEs do not go public, so they do not require SMEs to provide social assistance. This result support research by Dzigba (2015); Kryvko and Reichling (2012); Postnova (2012) that corporate governance cannot reduce credit risk. However, these findings do not support Dao and Pham (2015); Ko et al. (2019) that found corporate governance can reduce credit risk.

Hypothesis 4 states that independence can mitigate the credit risk. Table 1 resulted that the independence coefficient is 0.192 , $t$-value of 0.706 which significant at 0.481 that is greater than 0.05 , because the significance level is greater than 5\% so hypothesis 4 is rejected. The independence cannot reduce credit risk at the significance level of $5 \%$. This means, SMEs' management is a predominantly one-man show or single fighter (Hanifah, 2015) so that SMEs are not professionally managed and pressure from any party. SMEs are unable to act professionally in every decision making; SMEs are often subjective in making decisions and actions, and often prioritize their personal, family and group interests. These results supported by the status of ownership of SMEs, where the majority of which are $53 \%$ of individual ownership, family ownership is $29 \%$. This ownership is very difficult to act independently, constantly put personal and family interests first, mixing business and personal finances, irregularities in the use of capital often occur so it cannot reduce credit risk. This results support research by Dzigba (2015); Kryvko and Reichling (2012); Postnova (2012) that corporate governance cannot reduce credit risk. However, these findings do not support research by Dao and Pham (2015); Ko et al. (2019) that corporate governance can reduce credit risk.

Hypothesis 5 states that fairness has a negative influence on credit risk. Table 1, it shows that fairness has a coefficient of 0.426 , t-value of 1.626 which significant at 0.105 that is greater than 0.05 , because the significance level is greater than $5 \%$ so hypothesis 5 is rejected. It indicated that fairness cannot reduce credit risk. The justice and equality system implemented by SME managers has not been able to fulfill the rights of banks and other stakeholders so that the implementation of fairness cannot reduce the credit risk. This is supported by value of fairness of 3.404 (medium) that SMEs have treated the stakeholders fairly which arises based on relevant laws and regulations, but has not been maximized. Hence, fairness cannot reduce credit risk. The results of this study support research by Dzigba (2015); Kryvko and Reichling (2012); Postnova (2012) that corporate governance in SMEs is still low so that it cannot reduce credit risk. However, these findings do not support research by Dao and Pham (2015); Ko et al. (2019) that corporate governance can reduce credit risk.

Hypothesis 6 states that financial literacy can strengthen the effect of transparency on credit risk. Based on the regression result, the value of interaction between financial literacy and transparency is 0.165 with a $\mathrm{t}$-value of 2.910 which significant at 0.004 , because the significance level is smaller than 0.05 , so hypothesis 6 is accepted at $5 \%$ level of significance. This indicates financial literacy is able to strengthen the effect of transparency in reducing credit risk. The results show that financial literacy shown by knowledge, understanding, and skills of SMEs in managing finances are able to strengthen SMEs in financial reports quickly, correctly to both creditors and other stakeholders. This finding is in line with Hussain and Matlay (2007) that financial literacy can reduce asymmetric information, reduces monitoring costs, and improves capital flows. This financial literacy can strengthen transparency, as indicated by the reduction of asymmetric information between creditors and debtors by reducing monitoring costs, thereby reducing credit risk. This results supported by Belas et al. (2018); Mutegi et al. (2015) that financial literacy can reduce credit risk. This is supported by the knowledge and skills in financial management. This result is explained by the collaboration between agency theory and resource-based theory. This study do not support research by Dzigba (2015); Kryvko and Reichling (2012); Postnova (2012) that the corporate governance in SMEs is still low, thus it cannot reduce credit risk, even though it is strengthened by financial literacy.

Hypothesis 7 states that financial literacy is able to strengthen the effect of accountability on credit risk. Table 1 shows that the interaction coefficient between financial literacy and accountability is 0.148 , t-value of 2.273 which significant at 0.024 , because the significance level is smaller than 0.05 , hence hypothesis 7 is accepted. The results show that financial literacy can moderate the effect of accountability on credit risk at 5\% level significance. Thus, SME managers who have the knowledge, understanding and skills of SMEs in reporting are proven to be able to strengthen the effect of implementing accountability in reducing credit risk. This supports research by Belas 
et al. (2018); Mutegi et al. (2015) that financial literacy will encourage SME managers to be able to plan and evaluate financial with guidelines, and solve credit problems. Therefore, the accountability as corporate governance mechanism will be effective in reducing credit risk if it is supported by the knowledge and skills of SME managers in financial management. This was explained by the collaboration between agency theory and resource-based theory. The results support research by Dzigba (2015); Kryvko and Reichling (2012) that CG can reduce credit risk if it is strengthened by financial literacy.

Hypothesis 8 states that financial literacy can strengthen the effect of responsibility on credit risk. Based on the statistic results, the interaction value between literacy of financial and responsibility is 0.170 with a t-value of 2.374 which significant at 0.020 , because the significance level is smaller than $5 \%$, so hypothesis 8 is accepted. The results show that financial literacy can moderate the effect of responsibility on credit risk at $5 \%$ level significance. This means that knowledge, understanding, and skills of SME managers in managing finances are able to strengthen the effect of responsibility in reducing credit risk. This results support Hussain and Matlay (2007); Hussain et al. (2018); Siekei et al. (2013) that credit management skills help SME managers in managing loan portfolios to ensure that interest costs are minimized, so that credit risk decreases. Wise (2013) found that financial literacy can strengthen managers' ability to use complex financial knowledge, improve social networks, communication, and skills in the financial sector as SMEs' responsibility to external parties. Likewise, Hussain and Matlay (2007); Hussain et al. (2018) explained that financial education can reduce asymmetric information and reduce monitoring costs as an implementation of corporate governance, so that credit risk can be reduced. The implementation of responsibility as a corporate governance mechanism will be effective in reducing credit risk, if it is supported by financial literacy. This result was explained by the collaboration between agency theory and resource-based theory. This results support research by Dzigba (2015); Kryvko and Reichling (2012); Postnova (2012) that practices of CG in SMEs is still low, hence it cannot reduce credit risk, even though it is strengthened by financial literacy.

Hypothesis 9 states that financial literacy can strengthen the effect of independence on credit risk. The statistic result show that the interaction value between financial literacy and independence is -0.023 with a t-value of -0.308 which significant at 0.759 , because the significance level is greater than $5 \%$, so hypothesis 9 is rejected at $5 \%$ level of significance. It means that the knowledge, understanding, and skills of SMEs in managing finances cannot strengthen SMEs in acting independently in financial decision making so that it does not affect credit risk. This is due to the characteristics of SMEs in Indonesia which are family businesses so there is no separation between managers and owners because there is only one person who dominates the business process and decision making, hence this affects the weak level of independence (Kurniawati et al., 2018). This results support research by Menike (2019) that SMEs tend to follow the habits of their parents and their life experiences about financial management. SME managers tend to manage business and finance following the culture and values of business owners Agyei (2018). This means, SME managers get difficulties to be independent, so they ignore financial literacy which can reduce credit risk. This study also supports research by Dzigba (2015); Kryvko and Reichling (2012); Postnova (2012) that corporate governance in SMEs is still poor, therefore it cannot reduce credit risk, even though it is strengthened by financial literacy. This result is inconsistent with Belas et al. (2018); Mutegi et al. (2015) that financial literacy can reduce credit risk and Hussain and Matlay (2007); Hussain et al. (2018) that financial education can reduce asymmetric information as an implementation of corporate governance, hence credit risk can be minimized.

Hypothesis 10 states that financial literacy can strengthen the effect of fairness on credit risk. However, in Table 1, the interaction coefficient value between the financial literacy and fairness is -0.083 with -1.199 ( $\mathrm{t}$ value), 0.232 (significant value), because the significance level is greater than $5 \%$, so hypothesis 10 is rejected at $5 \%$ level of significance. Financial literacy is not effective in strengthening the effect of fairness in reducing credit risk at $5 \%$ level of significance. The knowledge, understanding, and skills of SMEs in managing finances including making financial reports cannot strengthen the effect of fairness in reducing credit risk. This is because the management of SMEs is still a one-man show or family business. Habit of SMEs are follow their parents, their life experiences and financial management knowledge (Menike, 2019) and SME managers tend to manage business and finance following the culture and values of owners (Agyei, 2018). Hence, SME managers are very difficult to be fairness, and they ignore financial literacy which can reduce credit risk. This is support by Dzigba (2015); Hussain et al. (2018); Kryvko and Reichling (2012); Postnova (2012) that the corporate governance in SMEs is still poor so that it cannot reduce credit risk, even though it is strengthened by financial literacy. Also, this does not support research by Belas et al. (2018); Mutegi et al. (2015) that knowledge of financial is one of the non-economic factors that can reduce credit risk.

\section{Conclusions}

SMEs have a strategic role in increasing employment and economic growth. However, it is difficult for SMEs to develop because they have limited financial access, do not have collateral and higher credit risk. Aims this study to analyze the role of financial literacy in strengthening role of CG: transparency, accountability, responsibility, independence and fairness in reducing SMEs' credit risk. This result showed that corporate governance shown by responsibility, independence and fairness cannot reduce 
SMEs credit risk, however transparency and accountability could. After being moderated by financial literacy, this study found that transparency, accountability and responsibility as corporate governance mechanism can reduce credit risk. CG will be effective in reducing credit risk if SME managers have knowledge, understanding and skills of financial management. Also, the implementation of corporate governance does not have an impact in reducing credit risk if SME managers low level of financial knowledge. The implementation of corporate governance will be effective if it is supported by the financial knowledge and financial competency that must be possessed by SME managers, so that further, it can reduce credit risk.

This study has some limitations. It only examines the implementation of corporate governance mechanisms in reducing credit risk in SMEs that do not go public in capital market. Therefore, it can be compared with corporate governance in reducing credit risk in SMEs that go public. Also, this study is only a cross section, it is expected that future research can be developed with times series and panel data, so that the results will be better and more comprehensive.

For practical implication, Indonesian government, financial institution and education institution must collaborate to give the education and training to increase SMEs' financial literacy. So, SMEs can make the financial decision better, can implement corporate governance, consequently credit risk decreases. In addition, the Indonesian government must improve the corporate governance regulations specifically for SMEs. Lastly, for theoretical implication, this study should develop corporate governance models based on collaborative between agency theory and resource-based view theory to analysis the CG mechanism and financial literacy for SMEs is needed so can reduce credit risk.

\section{References}

Abor, J., \& Adjasi, C. K. D. (2007). Corporate governance and the Small and Medium Enterprises Sector: Theory and implications. Corporate Governance: The International Journal of Business in Society, 7(2), 111-122.

https://doi.org/10.1108/14720700710739769

Adomako, S., Danso, A., \& Damoah, J. O. (2016). The moderating influence of financial literacy on the relationship between access to finance and firm growth in Ghana. Venture Capital, 18(1), 43-61. https://doi.org/10.1080/13691066.2015.1079952

Agyei, S. K. (2018). Culture, financial literacy, and SME performance in Ghana. Cogent Economics and Finance, 6(1). https://doi.org/10.1080/23322039.2018.1463813

Andrews, A., \& Gikunoo, E. (2011). Small scale foundries in Ghana: the challenges. Leonardo Electronic Journal of Practices and Technologies, 10(19), 1-12.

Ansong, A. (2013). Risk management as a conduit of effective corporate governance and financial performance of Small and Medium scale enterprises. Developing Country Studies, 3(8), 159-164.

Belas, J., Smrcka, L., Gavurova, B., \& Dvorsky, J. (2018). The impact of social and economic factors in the credit risk management of SME. Technological and Economic Development of Economy, 24(3), 1215-1230.

https://doi.org/10.3846/tede.2018.1968
Ciftci, I., Tatoglu, E., Wood, G., Demirbag, M., \& Zaim, S. (2019). Corporate governance and firm performance in emerging markets: evidence from Turkey. International Business Review, 28(1), 90-103. https://doi.org/10.1016/j.ibusrev.2018.08.004

Dao, B. T., \& Pham, H. (2015). Corporate governance and bank credit risk: default probability, distance to default. SSRN Electronic Journal, 1-22. https://doi.org/10.2139/ssrn.2708994

Dzigba, D. (2015). Corporate governance practice among Small and Medium Scale Enterprises (SMEs) in Ghana; Impact on access to credit [Thesis, Blekinge Tekniska Högskola].

Eniola, A. A., \& Entebang, H. (2015). Financial literacy and SME firm performance. International Journal of Research Studies in Management, 5(1), 31-43.

https://doi.org/10.5861/ijrsm.2015.1304

Fatoki, O. (2014). The financial literacy of micro entrepreneurs in South Africa. Journal of Social Sciences, 40(2), 151-158. https://doi.org/10.1080/09718923.2014.11893311

Fülöp, M. T. (2014). Why do we need effective corporate governance? International Advances in Economic Research, 20(2), 227-228. https://doi.org/10.1007/s11294-013-9430-3

Glaser, M., \& Walther, T. (2013). Run, walk, or buy? Financial literacy, dual-process theory, and investment behavior. SSRN Electronic Journal. https://doi.org/10.2139/ssrn.2336109

Handriani, E., \& Robiyanto, R. (2019). Institutional ownership, independent board, board size, and firm performance: evidence from Indonesia. Contaduría Y Administración, 64(3), 1-16. https://doi.org/10.22201/fca.24488410e.2018.1849

Hanifah. (2015). The implementation of good corporate governance in efforts to increase profit in Small Medium Enterprises (SMEs). International Journal of Business, Economics and Law, 7(3), 38-45.

Hussain, J., \& Matlay, H. (2007). Financing preferences of ethnic minority owner/managers in the UK. Journal of Small Business and Enterprise Development, 14(3), 487-500. https://doi.org/10.1108/14626000710773565

Hussain, J., Salia, S., \& Karim, A. (2018). Is knowledge that powerful? financial literacy and access to finance: An analysis of enterprises in the UK. Journal of Small Business and Enterprise Development, 25(6), 985-1003. https://doi.org/10.1108/JSBED-01-2018-0021

Jensen, M. C., \& Meckling, W. H. (1976). Theory of the firm: Managerial behavior agency costs and ownership structure. Journal of Financial Economics, 3(4), 305-360. https://doi.org/10.1016/0304-405X(76)90026-X

Ko, C., Lee, P., \& Anandarajan, A. (2019). The impact of operational risk incidents and moderating influence of corporate governance on credit risk and firm performance. International Journal of Accounting and Information Management, 27(1), 96-110. https://doi.org/10.1108/IJAIM-05-2017-0070

Kolapo, T. F., Ayeni, R. K., \& Oke, M. O. (2012). Credit risk and commercial banks' performance in Nigeria: A Panel model approach. Australian Journal of Business and Management Research, 2(2), 31-38.

Kryvko, A. \& Reichling, P. (2012, April 19). Corporate governance and performance of European commercial banks. In International Conference "Improving Financial Institutions: The Proper Balance between Regulation and Governance" (pp. 1-20). Helsinki.

Kurniawati, S. L., Sari, L. P., \& Kartika, T. P. D. (2018). Development of good SME governance in Indonesia: An empirical study of Surabaya. International Journal of Economics and Management, 12(1), 305-319.

Lusardi, A., \& Mitchell, O. S. (2014). The economic importance of financial literacy: Theory and evidence. Journal of Economic Literature, 52(1), 5-44. https://doi.org/10.1257/jel.52.1.5 
Lusardi, A., \& Scheresberg, C. de B. (2013). Financial literacy and high-cost borrowing in the United States. In Global Financial Literacy Excellence Center Working Paper No. 2013-1. https://doi.org/10.2139/ssrn.2585243

Maseko, N., \& Manyani, O. (2011). Accounting practices of SMEs in Zimbabwe: An investigative study of record keeping for performance measurement (a case study of Bindura). Journal of Accounting and Taxation, 3(8), 171-181. https://doi.org/10.5897/JAT11.031

Menike, L. M. C. S. (2019). Effect of financial literacy on firm performance of Small and Medium Enterprises in Sri Lanka. In 2019 Financial Markets \& Corporate Governance Conference (pp. 1-25). https://doi.org/10.2139/ssrn.3306719

Mutamimah. (2020). Financial technology and E-corporate governance model for Small Medium Enterprises. In Advances in Intelligent Systems and Computing (Vol. 993, pp. 907-913). Springer International Publishing. https://doi.org/10.1007/978-3-030-22354-0_84

Mutamimah, \& Hendar. (2017, December 13-14). Islamic financial inclusion: Supply side approach. In 5th ASEAN International University Conference on Islamic Finance (5th AICIF). Jerudong Brunei Darussalam.

Mutegi, H. K., Njeru, P. W., \& Ongesa, N. T. (2015). Financial literacy and its impact on loan repayment by small and medium enterprenuers: an analysis of the effect of book keeping skills from equity group foundation's financial literacy training program on enterpreneurs' loan repayment performance. International Journal of Economics, Commerce and Management, 3(3), 1-28.
Mutezo, A. (2013). Credit rationing and risk management for SMEs: the way forward for South Africa. Corporate Ownership and Control, 10(2), 153-163. https://doi.org/10.22495/cocv10i2c1art1

Okello, G. C. B., Ntayi, J. M., Munene, J. C., \& Malinga, C. A. (2017). The relationship between access to finance and growth of SMEs in developing economies: Financial literacy as a moderator. Review of International Business and Strategy, 27(4). https://doi.org/10.1108/RIBS-04-2017-0037

Postnova, A. (2012). Does good corporate governance reduce credit risk? [Department of Economics, Hanken School of Economics]. Helsinki. https://helda.helsinki.fi/dhanken/bitstream/ handle $/ 10138 / 37072 /$ postnova.pdf? sequence $=5$ \&isAllowed $=y$

Saeed, A., Javed, A. Y., \& Noreen, U. (2018). Microfinancing, governance, and performance: A South Asian perspective. Journal of Economics, Finance and Administrative Science, 23(46), 247-265. https://doi.org/10.1108/JEFAS-01-2017-0014

Siekei, J., Wagoki, J., \& Kalio, A. (2013). An assessment of the role of financial institutions in financing Small and Medium Enterprises (SME's) in Ghana. International Journal of Innovative Research \& Development, 2(8), 111-124.

Smith, S. W. (2011). Beg, borrow, and deal? Entrepreneurs' choice of financing and new firm innovation. SSRN Electronic Journal. https://doi.org/10.2139/ssrn.1573685

Wernerfelt, B. (1984). A resource-based view of the firm. Strategic Management Journal, 5(2), 171-180. https://doi.org/10.1002/smj.4250050207

Wise, S. (2013). The impact of financial literacy on new venture survival. International Journal of Business and Management, 8(23), 30-39. https://doi.org/10.5539/ijbm.v8n23p30 